\title{
Chloride Ion Diffusion in Low Water-To-Solid Cement Pastes
}

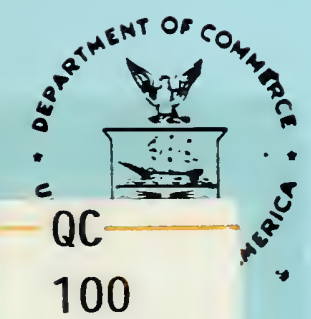

. U56

\#4549

1991

C. 2
Prepared for:

U.S. Nuclear Regulatory Commission Washington, DC 20555 
NATIONAL INSTITUTE OF STANDARDS \& TECHNOLOGY

Research Information Center

Gaichersburg, MD 20699 


\section{Chloride Ion Diffusion in Low Water-To-Solid Cement Pastes}

James R. Clifton

Lawrence I. Knab

Edward J. Garboczi

Lin Xian Xiong*

* Shanghai Research Institute

Shanghai, China

April 1991

U.S. Department of Commerce

Robert A. Mosbacher, Secretary

National Institute of Standards and Technology

John W. Lyons, Director

Building and Fire Research Laboratory

Gaithersburg, MD 20899
Prepared for:

U.S. Nuclear Regulatory Commission Washington, DC 20555 



\section{ABSTRACT}

Diffusion coefficients of 0.3 water to solids rato (w/s) hydrated portland cement paste specimens were measured using a conventional diffusion cell. Specimens were made from both ASTM Type I and Type II portland cements and blends containing mineral admixtures (fly ash, granulated blastfurnace slag, or silica fume). The average diffusion coefficient for the portland cement paste specimens was $14 \times 10^{-13} \mathrm{~m}^{2} / \mathrm{s}$. The diffusion coefficients for the specimens containing mineral admixtures were much more variable than those for the portland cement paste specimens. A probable cause of the variability in the test results was the presence of cracks observed in the test specimens.

The effects of the depth of concrete cover over reinforcing steel and of the chloride ion diffusion coefficient on the service life of reinforced concrete exposed to chloride ions were predicted based on a diffusion model. Based on the model, the effect of the cover was shown to be proportional to the square of the cover depth. A 10-fold decrease in the diffusion coefficient of concrete was predicted to result in a 10-fold increase in the predicted service life.

Based on the results of the present study, it is recommended that a new chloride diffusivity test should be developed which is applicable to concrete. A candidate test method is proposed.

KEYWORDS: Cement; chloride ion; concrete; corrosion; diffusion coefficient; service life. 
Table of contents

1. Introduction............................... 1

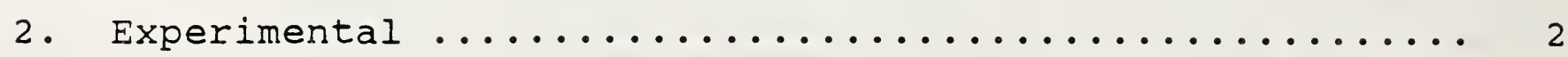

2.1 Hardended Cement Paste specimens .............. 2

2.2 Diffusion Test Method and Calculations ........... 2

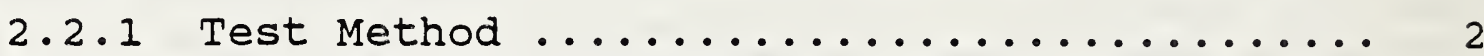

2.2 .2 Calculation of diffusion coefficients ..... 9

2.3 Observation of Cracks in Disks .............. 10

3. Test Results and Discussion ..................... 12

4. Need for a New Diffusion Test Method ................ 14

5. Effect of Chloride Ion Diffusivity on Service Life .... 16

6. Summary and Recommendations .................... 21

7. Acknowledgements ............................ 22

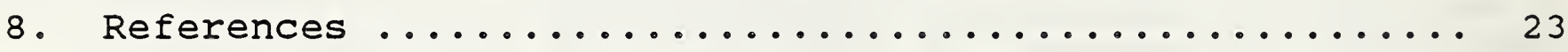




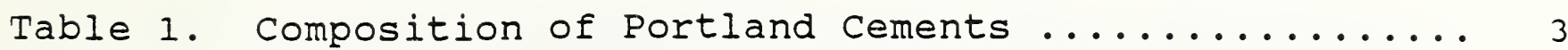

Table 2. Composition of Mineral Admixtures .............. 4

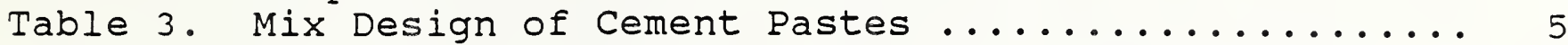

Table 4. Compressive Strength of Hardened Cement Paste .... 6

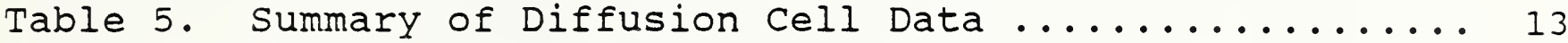

Table 6. Service Life of Reinforced Concrete ........... 20

Figure 1. Schematic of diffusion cell ................ 7

Figure 2. Photograph of complete diffusion cells .........8

Figure 3. Plot of diffusion data. Slope of line is the effective diffusion coefficient ................ II

Figure 4. Conceptual model of corrosion of steel

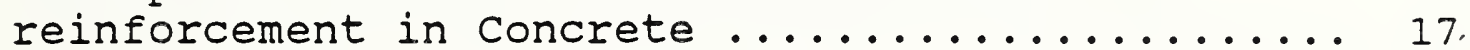

Figure 5. Schematic of reinforced concrete element and

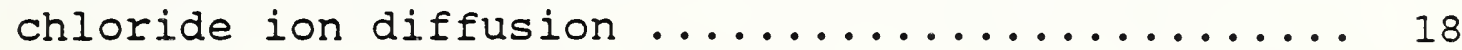





\section{INTRODUCTION}

Corrosion of steel reinforcement is one of the potentially serious degradation problems that could affect the structural stability of concrete structures used for disposal of storing low-level radioactive waste (1). The corrosion products of steel occupy a volume several times $(2,3)$ that of the original iron, which can result in the development of internal tensile stress leading to cracking of the concrete. If corrosion proceeds unabated, it may ultimately result in the destruction of reinforced concrete. Also, reduction in the cross section of the reinforcement, because of corrosion, will decrease its load carrying capacity.

Portland cement concrete normally provides an internal. environment which protects reinforcing steel from corrosion. The high alkaline environment $(\mathrm{pH}>12.5)$ in concrete results in the formation of a tightly adhering iron (III) oxide film which passivates the steel and thereby protects it from corrosion (2). However, the corrosion of steel embedded in concrete has become a serious problem in recent years, which has been attributed largely to the depassivating effect of chloride ions. Chloride ions can accelerate the corrosion rate of reinforcing steel so that corrosion can become serious problem within a few years after construction (2).

Chloride ions are common in nature and small amounts are usually unintentionally contained in the mix ingredients of concrete. Chloride ions also may be intentionally added, most often as a constituent of accelerating admixtures. The sources of chloride ion which are causing most of the problems, however, are deicing salts (usually calcium chloride) and sea water. Ground water may be contaminated with chloride ions from natural deposits and chlorides ions coming from runoff water, e.g., from bridges or pavements treated with deicing salts.

The service life of reinforced concrete exposed to sufficient chloride ions to accelerate the corrosion of the reinforcement is largely controlled by the rate that chloride ions penetrate concrete (3). Several models have been developed to predict the service life of reinforced concrete which are based on the diffusion rates of chloride ions $(3,4,5,6)$. To solve such models and to predict the service life of reinforced concrete, diffusion studies of concrete (7) and cements ( $8,9,10)$ have been carried out. The purpose of the present study was to investigate the feasibility of measuring chloride ion diffusion coefficients of cementitious materials. Also, the effect of the chloride diffusion coefficient on the service life of reinforced concrete was investigated using a diffusion model. 


\section{1 Hardened Cement Paste specimens}

Neat cement paste specimens were made using one ASTM Type I, identified as $I$, and two Type II portland cements, identified as II-A and II-M. Their oxide compositions are given in Table 1. Blast furnace slag (BFS), fly ash (FA), and silica fume (SF) were blended with the cements and the compositions of these mineral admixtures are given in Table 2. Blends of the portland cements and the mineral admixtures were made using the mix proportions given in Table 3. All the mixes were made with a water-to-solids ratio, w/s, of 0.3 . To each $\mathrm{mix}$, either 24 or $32 \mathrm{~g}$ of a commercial superplasticizer was added as a dry powder to the mix water. The cement pastes were mixed, with minor exceptions, according to the procedures given in ASTM C 305 (11). Cement pastes were cast in either $51 \mathrm{~mm}$ cube molds or cylindrical molds which were $76 \mathrm{~mm}$ high and had a diameter of $38 \mathrm{~mm}$. The molds were mechanically vibrated to minimize air bubbles and placed in a watertight plastic bag. After 1 day, the specimens were stripped and immersed in saturated lime water at $22^{\circ} \mathrm{C}$ until tested. They were tested between 67 to 139 days after being prepared. Specimens for diffusion tests were cut from either the cylinders or cubes with a diamond blade wafering saw. Interior slices, either 3 or $5 \mathrm{~mm}$ thick, were used for testing to avoid surface artifacts which could be caused by bleeding, surface finishing, or by casting.

The compressive strengths of the cubes were measured from 64 to 70 days of age following the procedures given in ASTM C-109 (12). The results are given in Table 4.

\subsection{Diffusion Test Method and Calculations}

2.2.1 Test Method. The diffusion test apparatus was similar to that described by clifton et. al., (13), and is shown Fig. 1. With most of the cells, a light coating of silicone vacuum grease was used between "O" ring and glass surfaces but not between "O" ring and cement paste surfaces. The exposed surfaces of the cement paste and the adjacent glass surfaces of the cell were sealed with a silicone rubber to prevent leakage from the cell. The complete cell was held in place by an acrylic frame (Fig. 2). The larger chamber (LC) was filled with 100 to $120 \mathrm{ml}$ of $1.0 \mathrm{~N}$ $\mathrm{NaCl}$ and the smaller chamber (SC) was filled with 39 to $46 \mathrm{ml}$ of deionized water. The cement disks were always kept wet or moist, throughout curing and testing. Even during the cell installation process, the disks were not allowed to dry out. Except when measurements were being made, the exposed openings of the cell compartments were sealed with rubber stoppers to prevent evaporation of the cell solutions. 
Table 1. Composition of Portland Cements

Portland Cements ${ }^{a}$

\begin{tabular}{|c|c|c|c|}
\hline Composition & $I$ & $I I-A$ & $I I-M$ \\
\hline $\mathrm{SiO}_{2}$ & 19.96 & 21.0 & 21.50 \\
\hline $\mathrm{Al}_{2} \mathrm{O}_{3}$ & 6.11 & 4.4 & 4.00 \\
\hline $\mathrm{Fe}_{2} \mathrm{O}_{3}$ & 2.36 & 3.1 & 5.20 \\
\hline $\mathrm{CaO}$ & 61.87 & 63.5 & 63.30 \\
\hline $\mathrm{MgO}$ & 3.02 & 3.4 & 2.40 \\
\hline $\mathrm{SO}_{3}$ & 3.22 & 2.94 & $n \cdot a \cdot{ }^{c}$ \\
\hline $\mathrm{Na}_{2} \mathrm{O}$ & 0.39 & 0.26 & 0.05 \\
\hline $\mathrm{K}_{2} \mathrm{O}$ & 0.75 & 0.50 & 0.52 \\
\hline $\mathrm{LOI}$ & 1.58 & 1.00 & 0.5 \\
\hline Ins. Res.b & n.a. & 0.34 & $\mathrm{n} \cdot \mathrm{a}$. \\
\hline $\mathrm{Mn}_{2} \mathrm{O}_{3}$ & 0.11 & n.a. & n.a. \\
\hline $\mathrm{P}_{2} \mathrm{O}_{5}$ & 0.28 & n.a. & $\mathrm{n} \cdot \mathrm{a}$. \\
\hline $\mathrm{TiO}_{2}$ & 0.33 & n.a. & $\mathrm{n} \cdot \mathrm{a}$. \\
\hline
\end{tabular}

${ }^{a}$ Designation by type of portland cement, $A$ and $M$ refer to sources. ${ }^{b}$ LOI is the loss on ignition; Ins. Res. is the insoluble residue. ${ }^{c}$ Not available. 
Table 2. Composition of Mineral Admixtures ${ }^{a}$

Composition

$\mathrm{SiO}_{2}$

$\mathrm{Al}_{2} \mathrm{O}_{3}$

$\mathrm{Fe}_{2} \mathrm{O}_{3}$

$\mathrm{TiO}_{2}$

$\mathrm{CaO}$

Mgo

$\mathrm{Na}_{2} \mathrm{O}$

$\mathrm{K}_{2} \mathrm{O}$

$\mathrm{SO}_{3}$

$\mathrm{P}_{2} \mathrm{O}_{5}$

LOI ${ }^{b}$

Carbon

\section{Blast}

Furnace Slaq

35.38

11.76

1.01

c

39.14

11.32

0.07

0.41

1.12

c

$1.35^{\mathrm{d}}$

c
Fly Ash

56.6

32.0

3.6

2.0

0.8

0.8

0.3

2.5

0.20

0.1

1.0

c
Silica Fume

$$
92-93
$$

$0.20-0.30$

$0.10-0.50$

c

$$
0.10-0.15
$$

$0.10-0.20$

0.10

0.10

0.10

c

c

$4-5$

${ }^{a}$ Compositions given as reported by sources of admixtures, in percent.

${ }^{b}$ LOI indicates loss on ignition.

${ }^{c}$ Not reported.

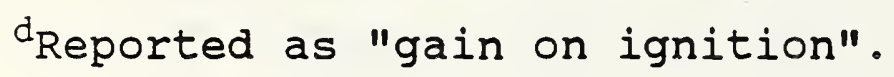


Table 3. Mix Design of Cement Pastes ${ }^{a}$

\begin{tabular}{|c|c|c|c|c|}
\hline Mix Code & $\begin{array}{l}\text { Mineral } \\
\text { Admixture }\end{array}$ & $\begin{array}{l}\text { Portland } \\
\text { Cement (g) }\end{array}$ & $\begin{array}{c}\text { Mineral } \\
\text { Admixture (g) }\end{array}$ & $\frac{\text { Wate }}{\text { Soli }}$ \\
\hline I & None & 4000 & -- & 0.3 \\
\hline$I I-A$ & None & 4000 & -- & 0.3 \\
\hline$I I-M$ & None & 4000 & -- & 0.3 \\
\hline$I-F A$ & Fly Ash & 2800 & 1200 & 0.3 \\
\hline$I I-A-F A$ & Fly Ash & 2800 & 1200 & 0.3 \\
\hline$I I-M-F A$ & Fly Ash & 2800 & 1200 & 0.3 \\
\hline$I-B F S$ & Blast Furnace Slag & 1400 & 2600 & 0.3 \\
\hline$I I-A-B F S$ & Blast Furnace Slag & 1400 & 2600 & 0.3 \\
\hline$I I-M-B F S$ & Blast Furnace Slag & 1400 & 2600 & 0.3 \\
\hline$I-S F$ & Silica Fume & 3600 & 400 & 0.3 \\
\hline$I I-M-S F$ & Silica Fume & 3600 & 400 & 0.3 \\
\hline
\end{tabular}

aTo each mix, $24 \mathrm{~g}$ superplasticizer were added, except for silica fume mixes to which $32 \mathrm{~g}$ superplasticizer added.

b
I = Type I Portland cement
II-M = Type II Portland Cement
BFS = Blast Furnace Slag
II-A = Type II Portland Cement
$F A=F l Y$ Ash
$S F=$ Silica Fume 
Table 4. Compressive Strength of Hardened Cement Pastes

Mix Designa

Average Compressive

strength, MPa

S.D. ${ }^{b}, \mathrm{MPa}$

I

73.9

8.9

I-BFS

76.3

5.7

$I-F A$

67.5

17.3

$I-S F$

59.8

2.9

II-A

101.5

10.9

II-A-BFS

77.5

7.1

$I I-A-F A$

66.2

12.1

II-M

63.1

$3 \cdot 6$

II-M-BFS

87.0

19.8

II-M-FA

77.0

3.6

II-M-SF

106.9

13.0

${ }^{a}$ See Table 3 for identification of mix design

bstandard deviation 


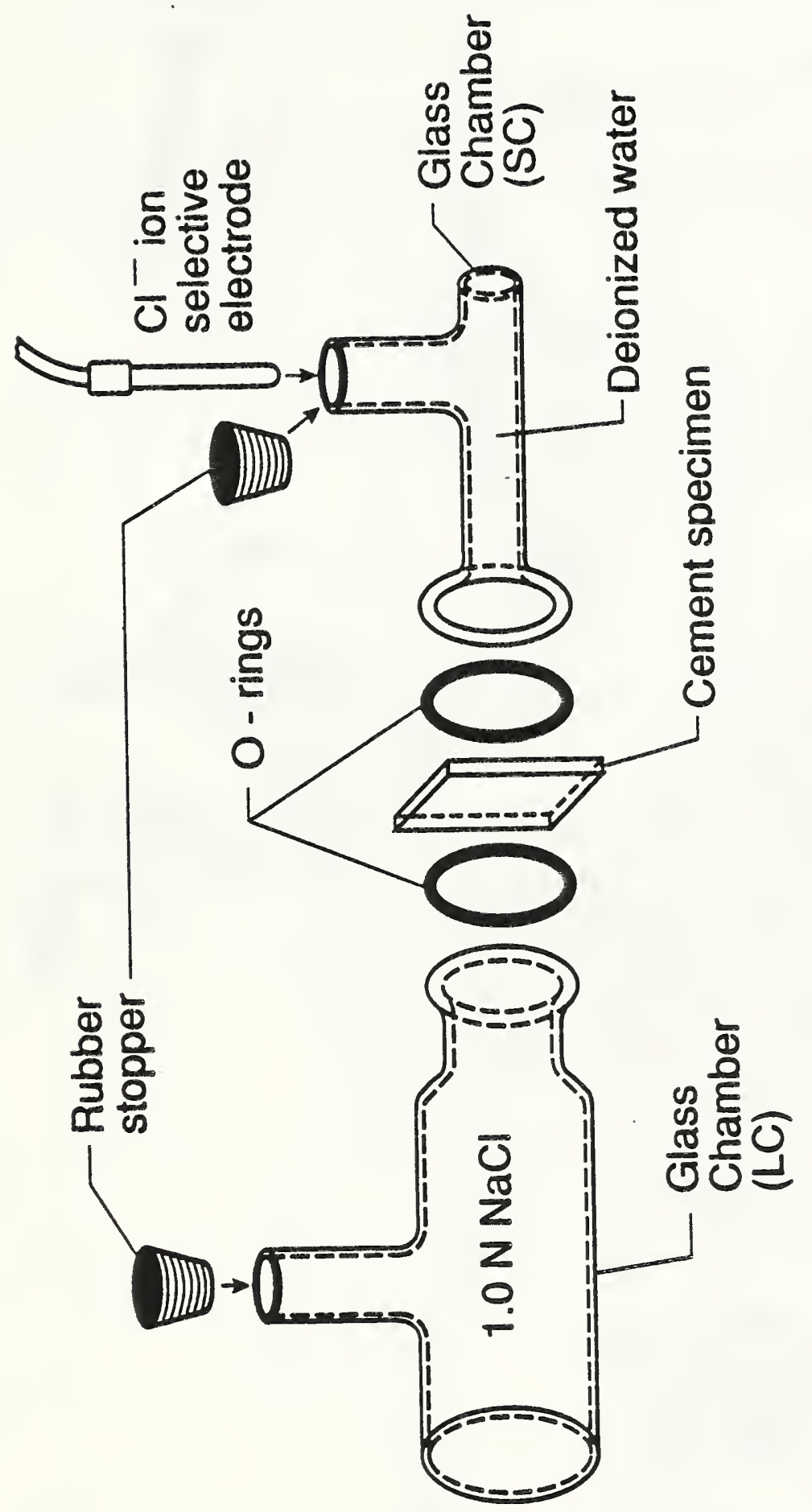

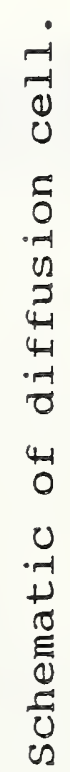




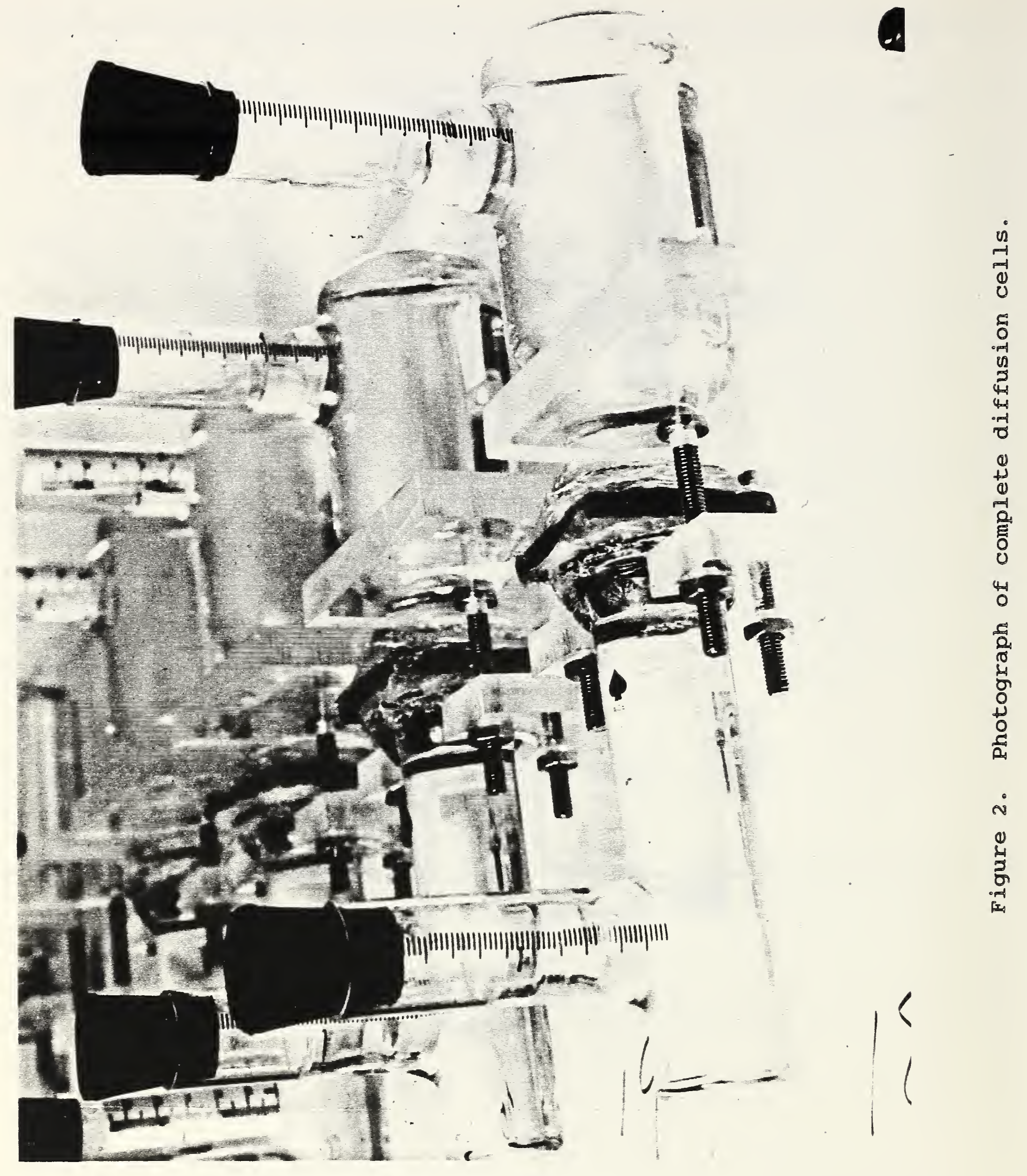


The amount of chloride ion diffusing through a hardened cement paste disk was measured using a combination chloride selective ion electrode. The electrode potential measurements, in $\mathrm{mV}$, were converted to chloride ion concentrations by a calibration curve made using $\mathrm{NaCl}$ standard solutions. The reproducibility of the electrode was checked regularly using deionized water and standard $\mathrm{NaCl}$ solutions.

Based on the observed diffusion results, it was concluded that in most cases, linear gradients were attained within 120 days of testing. Diffusion testing of specimens exhibiting the lower diffusivities (Specimen Nos. 5, 9, 18, and 23 (Table 5)) were continued for 16 months to ensure that steady state conditions were reached.

2.2.2. Calculation of diffusion coefficients. The calculation of the chloride ion diffusion constant was based on the onedimensional form of Fick's first equation (14):

$$
(1 / A) d Q / d t=-D d C / d x
$$

This equation relates the amount of chloride ions $Q$ diffusing through a cross-sectional area A per unit of time, dQ/dt, to the gradient of the concentration, $\mathrm{dc} / \mathrm{dx}$, and the diffusion coefficient, $D$.

In the diffusion experiments, diffusion took place from a cell with fixed concentration, $C_{1}(0)$, across a hardened cement paste into a second cell with initial chloride ion concentration of $c_{2}=0$. After a linear gradient was obtained at time $t$, the concentration gradient within the specimen was assumed to be everywhere the same and instantaneously equal to:

$$
\mathrm{dc} / \mathrm{dx}=\left(\mathrm{c}_{2}(t)-\mathrm{c}_{1}(t)\right) / \mathrm{H}
$$

where $\mathrm{H}$ is the thickness of the specimen in the direction of flow. In reality, the pore space of the hardened cement paste was inhomogeneous on length scales smaller than the thickness ( 3 to $5 \mathrm{~mm}$ ) of the specimens. By assuming that the cement paste was homogeneous (thin membrane approximation), the effective macroscopic diffusion constant was obtained. This procedure is conceptually similar to the determination of effective electrical conductivities and elastic moduli in inhomogeneous composite materials (15).

Substituting equation (2) for $d c / d x$ in equation (1) and rearranging, the following equation was obtained:

$$
d Q / d t=-D A\left(C_{2}(t)-C_{1}(t)\right) / H
$$


Using the boundary condition $c_{2}(0)=0$ and integrating, equation (3) becomes:

$$
D t=\frac{H V}{A} \ln \left[\frac{C_{1}(0) V}{C_{1}(0) V-C_{2}(t) V_{2}}\right]
$$

where $v_{1}$ and $v_{2}$ are the volumes of the solutions in the two cell compartments $\left(\mathrm{V}_{1}>\mathrm{V}_{2}\right), \mathrm{C}_{2}$ is the measured $\mathrm{Cl}^{-}$concentration of solution in compartment $S C$ at time $t$, and $V=V_{1} V_{2} /\left(V_{1}+V_{2}\right)$.

Assuming steady state conditions, a plot of the right hand side of equation (4) vs. $t$ should give a straight line whose slope is $D$, the effective diffusion coefficient of the cement paste specimens. A typical data plot is shown in Fig. 3. The zero slope portion of the plot reflects the time for the chloride ions to reach compartment $\mathrm{LC}$.

\subsection{Observation of Cracks in Disks}

The measured diffusion coefficients (Table 5) of four of the test specimens were substantially higher than the other specimens and, in some cases, considerable variability was found in the results for companion specimens. The presence of cracks was thought to be a likely reason for the higher diffusion values and the variability in the data. Therefore, 18 of the 23 specimens were examined for cracks within several days after they were removed from their diffusion cells. The examined disks were kept wet from the time they were removed from their cells until their examination. One or more cracks were visible in each of the 18 disks examined. The cracks usually extended from the edge of a disk into or very near the diffusion zone. Often the cracks extended completely through the disks. The crack widths were estimated for 7 disks using an optical microscope as being between 0.02 and $0.13 \mathrm{~mm}$. 


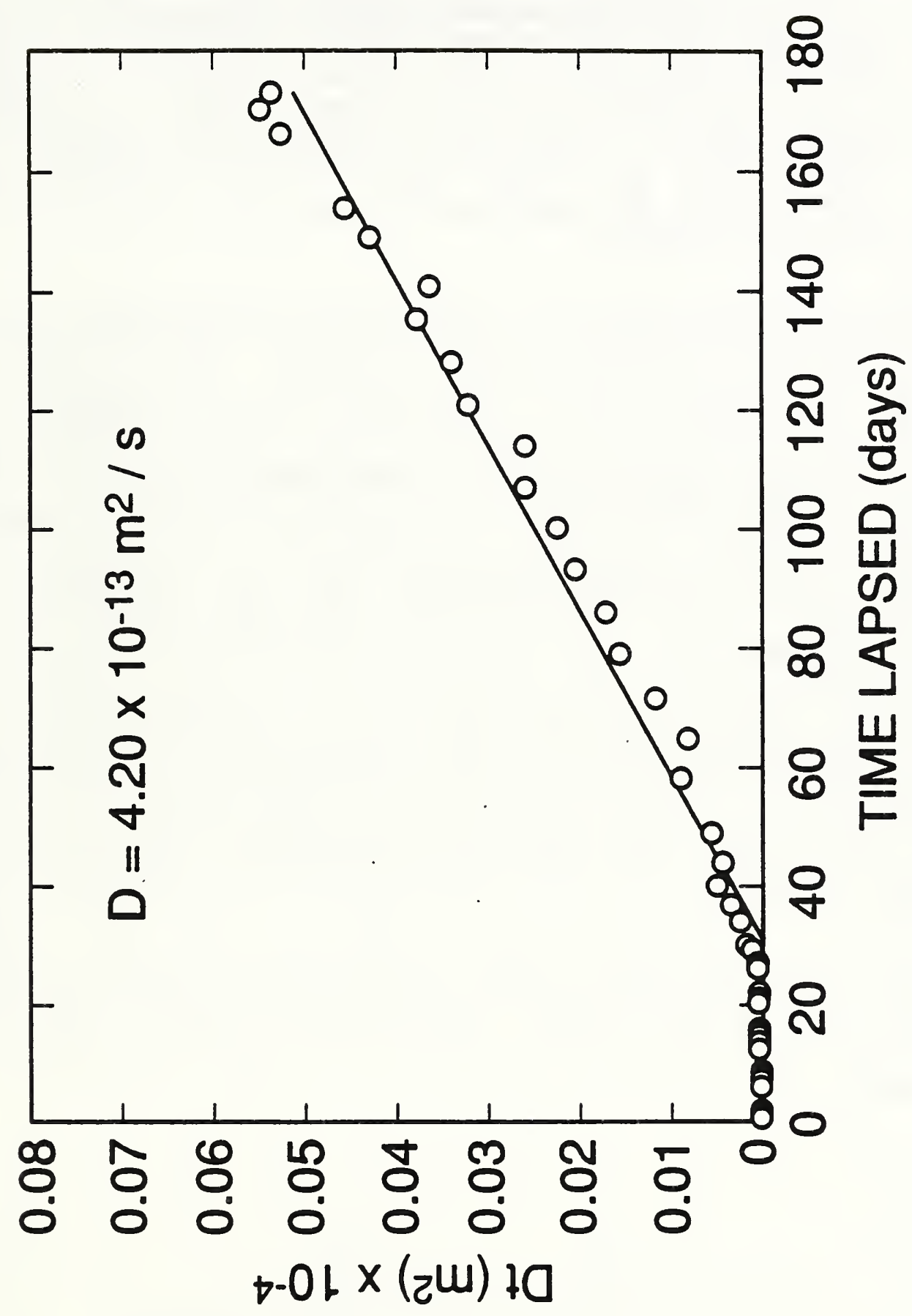




\section{TEST RESULTS AND DISCUSSION}

The experimentally determined diffusion coefficients are given in Table 5. Specimen Nos. 1, 2, 7, 8, and 13 through 16 can be considered control specimens as they did not contain any mineral admixtures. Calculating the average diffusion coefficient for these specimens, the result was $14 \times 10^{-13} \mathrm{~m}^{2} / \mathrm{s}$. This value is in the range $\left(5 \times 10^{-13} \mathrm{~m}^{2} / \mathrm{s}\right.$ to $\left.40 \times 10^{-13} \mathrm{~m}^{2} / \mathrm{s}\right)$ estimated by simulation modeling (16) of a portland cement paste with a w/s of 0.3 and which was hydrated to its maximum extent. Diffusion studies by Kumar (9) and Atkinson (10), also, gave diffusion coefficients similar to those measured in the present study for hardened portland cement pastes. The above comparisons suggest that the diffusion coefficient of around $14 \times 10^{-13} \mathrm{~m}^{2} / \mathrm{s}$ is near the intrinsic coefficient for portland cement at a $w / s$ of 0.3 , with no contribution by cracks.

The diffusion coefficients of specimens containing mineral admixtures were considerably more variable than the values obtained with pure portland cement pastes. For example, specimen No. 4, containing 30 percent fly ash (based on total solid mass) had a diffusion coefficient $60 \times 10^{-13} \mathrm{~m}^{2} / \mathrm{s}$, while its

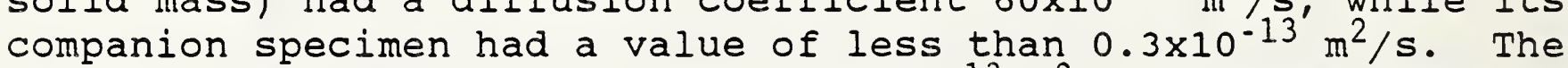
highest diffusion coefficient, $1400 \times 10^{-13} \mathrm{~m}^{2} / \mathrm{s}$ was obtained for specimen No. 6 which contained 10 percent, on a mass basis, of silica fume, while another specimen (No. 23) with silica fume gave a value of $0.56 \times 10^{-13} \mathrm{~m}_{2} \mathrm{~s}$ (note that the value for its companion specimen, No. 22 , was $58.0 \times 10^{-13} \mathrm{~m}^{2} / \mathrm{s}$ ). Similar, examples of variability were obtained with the specimens containing the blast furnace slag (e.g., compare specimen Nos. 9 and 10). A possible cause of the variability in the test results is the presence of cracks in the test specimens. According to Powers (17), hydrated portland cement-based materials with $\mathrm{w} / \mathrm{s}$ below that necessary for complete hydration, could exhibit desiccation cracking.

Analysis of the diffusivity data (Table 5) does not reveal any relationship between the curing time of the test specimens and their diffusion coefficients. The lack of such a relationship suggests that the specimens hydrated to their maximum extent before testing. 


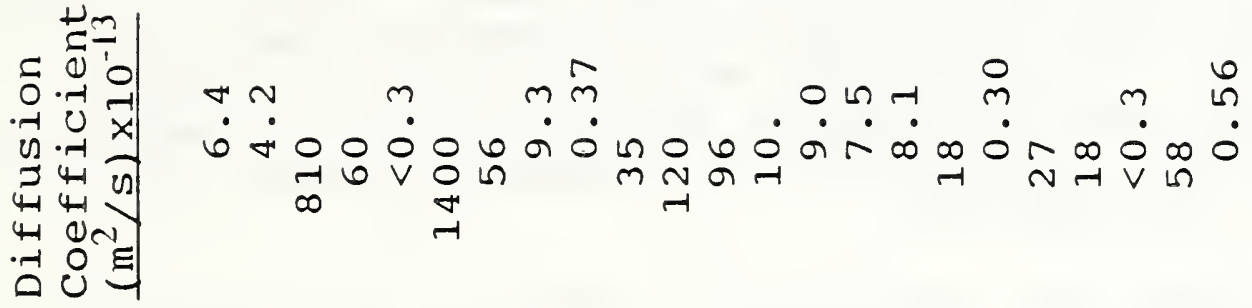

שִ

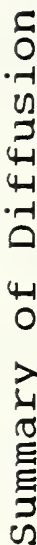

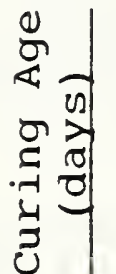

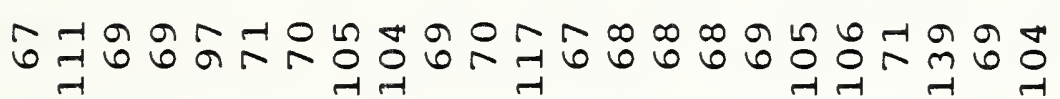

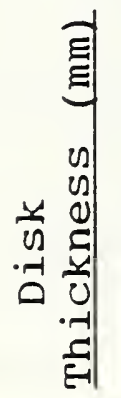

$\infty 00$, 0 - 0 H

$\dot{0}$

告

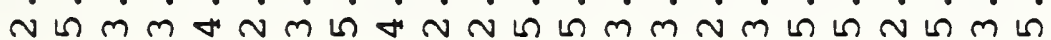

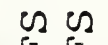

e $\quad$ की

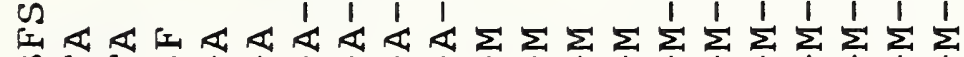

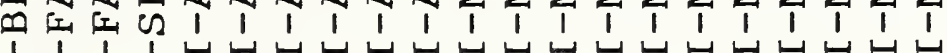

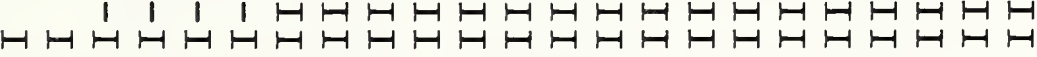

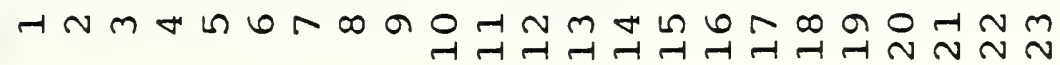

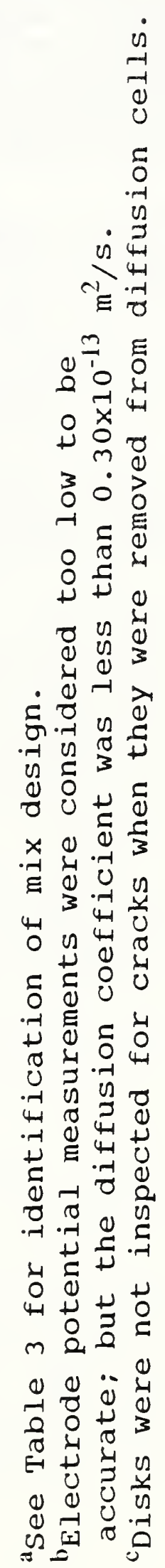




\section{NEED FOR A NEW DIFFUSION TEST METHOD}

Although the chloride diffusivity experiments were carefully carried out, the results had a wide scatter. Some specimens had abnormally low or high diffusivities, far beyond what could be reasonably expected for the materials used. Some disks were cracked, which could have also contributed to the scatter. Finally, months of data-taking were required to collect sufficient data for a diffusion coefficient to be determined. A more reliable and rapid method of determining chloride diffusivities is required.

There is a method that empirically attempts to assess the chloride diffusivity of concrete, called the "Rapid chloride Permeability Test" (18). This test is used in attempts to quantify the chloride diffusivity by measuring the total current that is passed through a water-saturated specimen in 6 hours under an applied DC potential of 60 volts. The Nernst-Einstein relation quantitatively relates diffusivity and conductivity, which is the physical motivation for this test. For plain portland cement concrete, this test appears to adequately rank different specimens according to their w/s ratio. However, this is only possible because the conductivity of the pore solution is about the same for various water:cement ratios.

The measured current in the Rapid Chloride Permeability Test (which is probably dominated by electrode polarization effects and thus is not measuring the true DC conductivity (19)) is directly proportional to the conductivity of the pore solution as well as the geometrical effect of a confining, tortuous pore network. Mineral admixtures such as silica fume appear to have the ability of greatly reducing the pore solution conductivity, possibly through the consumption of calcium ions. Therefore, $a$ silica fume-modified concrete may show an unusually low total current passed due only to the reduction in pore solution conductivity, and not to any significant microstructural change that would also be reflected in lower chloride diffusivity values. To determine the contribution of any true microstructural change would require knowledge of the pore solution conductivity.

Atkinson (10) has shown how the diffusivity can be rapidly and accurately measured using $A C$ electrical conductivity

measurements. The pore space is first saturated with a solution of an electrolyte with a high conductivity, and then the frequency-dependent electrical conductivity is measured and extrapolated back to zero. Finally, the diffusivity coefficient is calculated from its electrical conductivity. This technique removes the electrode polarization effects associated with DC measurements, and gives the true DC conductivity. This technique has been used successfully for many years in the oil-well logging industry, and uses standard commercial equipment. It has 
been used by Atkinson (10) with some success, but has not been carefuliy and thoroughly validated for cement-based materials. 
The effect of chloride ion diffusivity on the service life of reinforced concrete can be assessed based on the conceptual model of corrosion schematically represented in Fig. 4. According to this model, corrosion starts after the end of an initiation period (dormant period) which is followed by a propagation period (period of active corrosion). The corrosion process can be initiated by the diffusion of chloride ions to the depth of the reinforcing steel, or by the effect of carbonation reducing the $\mathrm{pH}$ of the pore liquid in contact with the steel, or by some combination of these two processes. Considering only the effect of chloride ions on the initiation period, its time is largely controlled by the rate of penetration of the chloride ions in the concrete and by the threshold concentration for the corrosion process. The threshold concentration is the chloride ion concentration necessary to induce corrosion. If the corrosion is induced by chloride ions and if sufficient oxygen is available to sustain corrosion, the service life can be roughly estimated by calculating the initiation period.

The initiation period is determined for the reinforced concrete element shown in Fig. 5 as follows. $C_{0}$ is the concentration of chloride ions at the outside surface of the concrete and $\mathrm{c}_{i}$ is the concentration at the depth of the reinforcement, which is assumed to be initially 0 . The initiation period is completed when $c_{i}=c_{t}$, the threshold concentration. The time for $c_{i}=c_{t}$ can be calculated using Fick's second law of diffusion (14):

$$
\frac{\partial C}{\partial t}=D \frac{\partial^{2} C}{\partial Z^{2}}
$$

where $C$ is the chloride ion concentration

$t$ is the time

$z$ is the distance

$D$ is the diffusion coefficient.

The general solution to equation No. (5) for the concrete element in Fig. 5 is:

$$
\frac{C}{C_{0}}(z, t)=\sum_{n=0}^{\infty}(-1)^{n}\left[\operatorname{erf}\left\{\frac{(2 n+1)-y}{2 \sqrt{x}}\right\}+\operatorname{erf}\left\{\frac{(2 n+1)+y)}{2 \sqrt{x}}\right\}\right]
$$

where erf is the error function (20),

$y=(L-x) / L$, and

$r=D t / L^{2}$.

$\mathrm{x}=$ depth of cover

$I=$ thickness of concrete element 


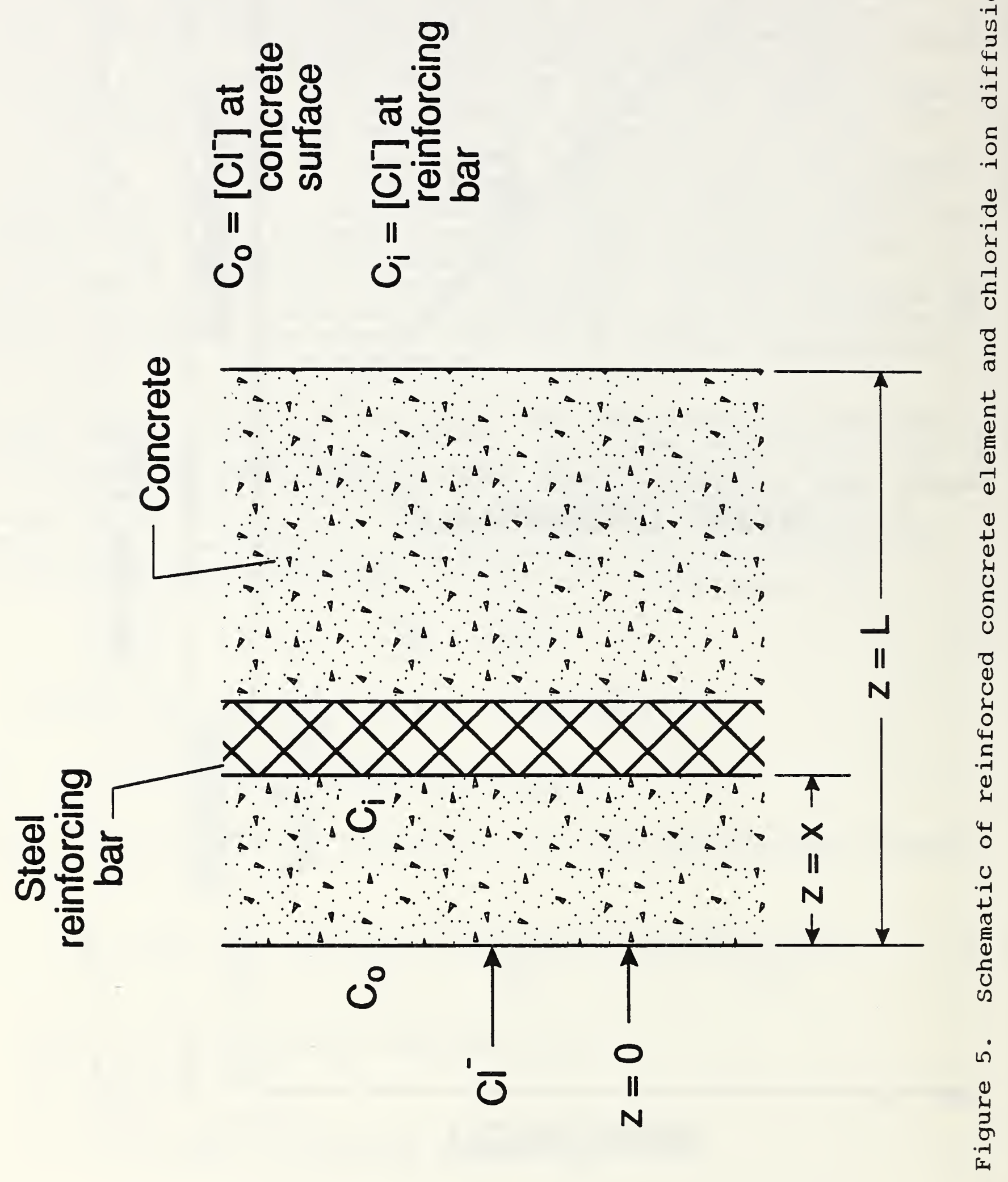


However, in the present case, only the $\mathrm{n}=0$ term of equation (6) needs to be considered (higher order terms have insignificant contributions to the summation); thus equation (6) reduces to:

$$
\frac{C}{C_{0}}=\operatorname{erf} \frac{(1-y)}{2 \sqrt{I}}
$$

where $1-y=x / L$.

In the present case, to achieve a service life of 500 years, for the parametric values of $D=5 \times 10^{-13} \mathrm{~m}^{2} / \mathrm{s}, \mathrm{x}=75 \mathrm{~mm}, \mathrm{~L}=300 \mathrm{~mm}$, and $C_{i}=0$ at $t=0$, the ratio of $C_{t} / C_{0}$ was set at 0.55 .

The effects of the depth of concrete cover over the reinforcing steel and the chloride ion diffusion coefficient of concrete are presented in Table 6 . The effect of the cover is proportional to $\mathrm{x}^{2}$. For example, increasing $\mathrm{x}$ from $25 \mathrm{~mm}$ to $100 \mathrm{~mm}$, increases the service life by a factor of $(100 / 25)^{2}$ or 16 . Therefore, proper placement of the reinforcing steel is vital, if the reinforced concrete is to attain its designed life.

The effect of the diffusion coefficient is significant as a 10fold decrease in it results in a 10-fold increase in the predicted service life. Therefore, accurate measurements of the chloride diffusion coefficients of concrete are necessary if accurate service life predictions are to be made. This reinforces the justification for the development of an accurate chloride ion diffusivity test. 
Table 6. Service Life of Reinforced Concrete (Years)a

Chloride Ion Diffusion Coefficient, $D\left(\mathrm{~m}^{2} / \mathrm{s}\right)$

$\begin{array}{llcc}\begin{array}{c}\text { Cover } \\ (\mathrm{mm})\end{array} & \underline{5 \times 10^{-11}} & \underline{5 \times 10^{-12}} & \underline{5 \times 10^{-13}} \\ 25 & 0.56 & 5.6 & 56 \\ 50 & 2.3 & 23 & 230 \\ 75 & 5 & 50 & 500 \\ 100 & 9 & 90 & 900\end{array}$

${ }^{a}$ Based on setting $C_{t} / C_{0}=0.55$ and $L=300 \mathrm{~mm}$. 


\section{SUMMARY AND RECOMMENDATIONS}

Diffusion coefficients of $0.3 \mathrm{w} / \mathrm{s}$ hardened portland cement paste specimens were measured using a conventional diffusion cell. Specimens were made from ASTM Type I and Type II portland cements and blends of them with mineral admixtures: fly ash, granulated blast furnace slag, or silica fume. The average diffusion coefficient for the portland cement paste specimens was $14 \times 10^{-13}$ $\mathrm{m}^{2} / \mathrm{s}$, which is in the range estimated by simulation modeling (16) of a portland cement paste with a w/s of 0.3 and hydrated to its maximum extent. The diffusion coefficients of specimens containing mineral admixtures were considerably more variable than the values obtained with pure portland cement pastes. A probable cause of the variability in the test results was the presence of cracks observed in the test specimens.

The effects of the depth of concrete cover over the reinforcing steel and the chloride ion diffusion coefficient on the service life of reinforced concrete exposed to chloride ions were predicted based on a diffusion model. The effect of the cover was shown to be proportional to square of depth of concrete cover. For example, increasing the cover from $25 \mathrm{~mm}$ to $100 \mathrm{~mm}$, should increase the service life by a factor of $(100 / 25)^{2}$ or 16 . Therefore, proper placement of the reinforcing steel is vital if the reinforced concrete is to attain its designed life. The effect of the diffusion coefficient is significant as a 10-fold decrease in it results in a 10-fold increase in the predicted service life. Therefore, accurate measurements of the chloride diffusion coefficients of concrete are necessary if accurate service life predictions are to be made.

Based on the results of the present study, it is recommended that a new chloride diffusivity test should be developed which is applicable to concrete. A proposed candidate for the new test involves measuring the $A C$ electrical conductivity of a concrete whose pore space is saturated with a solution of a chloride ion electrolyte with a high conductivity. 


\section{ACKNOWLEDGEMENTS}

The financial support for this research by the U.S. Nuclear Regulatory Commission (NRC) is acknowledged. Mr. Jacob Philip was the NRC Program Manager and his advice is greatly appreciated. The laboratory assistance provided by Mr. Edgardo colon, University of Puerto Rico, is gratefully acknowledged. 
8. REFERENCES

1. J.R. Clifton and L.I. Knab, "Service Life of Concrete," Report NUREG/CR-5466, U.S. Nuclear Regulatory Commission (1989).

2. "Corrosion of Metals in Concrete," ACI Journal, 3-32 (JanFeb, 1985).

3. K. Tuutti, "Corrosion of steel in concrete," Swedish cement and Concrete Research Institute, Stockholm (1982).

4. Z.P. Bazant, "Physical Model for steel corrosion in concrete Sea structures-Theory," ASCE Journal of the structures Division, Vol. 105 (ST6), 1137-1153 (June 1979).

5. Z.P. Bazant, "Physical Model for steel corrosion in Concrete Sea Structures-Application," ASCE Journal of the structures Division, Vol. 105 (ST6) 1155-1166 (June 1979).

6. R.D. Browne, "Mechanisms of Corrosion of steel in Concrete," in Concrete in Relation to Design, Inspection, and Repair of offshore and coastal structures, ACI SP-65

7. R.E. Weyers and D.G. Smith, "Chloride Diffusion Constants for Concretes," in Proceedings of structural Materials, pp. 106-115, (ASCE, 1989).

8. C.L. Page, N.R. Short, and A. El Tarras, "Diffusion of Chloride Ion," Cement and Concrete Research, 11, 395-406 (1981).

9. A. Kumar, "Diffusion and Pore structure studies in Cementitious Materials," Ph.D. Thesis, Pennsylvania state University (1985).

10. A. Atkinson and A.K., "The Diffusion of Ions Through WaterSaturated Cement," Journal of Materials Science, 19, 30683078 (1984).

11. ASTM C 305-82 (Reapproved 1987) "Standard Practice for Mechanical Mixing of Hydraulic cement Pastes and Mortars of Plastic Consistency", ASTM , Philadelphia, PA.

12. Standard Test Method for Compressive Strength of Hydraulic Cement Mortars, ASTM Designation C109-88.

13. J.R. Clifton, J.F. Becghly, and R.G. Mathey, "Nonmetallic Coatings for Concrete Reinforcing Bars," Building science Series 65, National Bureau of Standards (1975). 
14. M.I. Jacobs, "Diffusion Process," Springer - Verlag (New York, (1967).

15. J.P. Watt, G.F. Davies, and R.J. O'Connell, Review Geophyics and Space Physics, 14, 541 (1976).

16. E.J. Garboczi and D.P. Bentz, "Computer Simulation of the Diffusivity of Cement-Based Materials," Journal of Materials Science (in press).

17. T.C. Powers, "The Structure of Concrete," Cement and Concrete Association (London, 1965).

18. Rapid chloride permeability test Larry Knab provides

19. C.A. Scuderi, J.I. Mason, and H.M. Jennings, "Impedence Spectroscopy of Hydrating Cement Pastes," Journal of Materials science (in press).

20. F.S. Merritt, "Mathematics Manual," McGraw-Hill Book Company, Inc. (New York, 1962). 


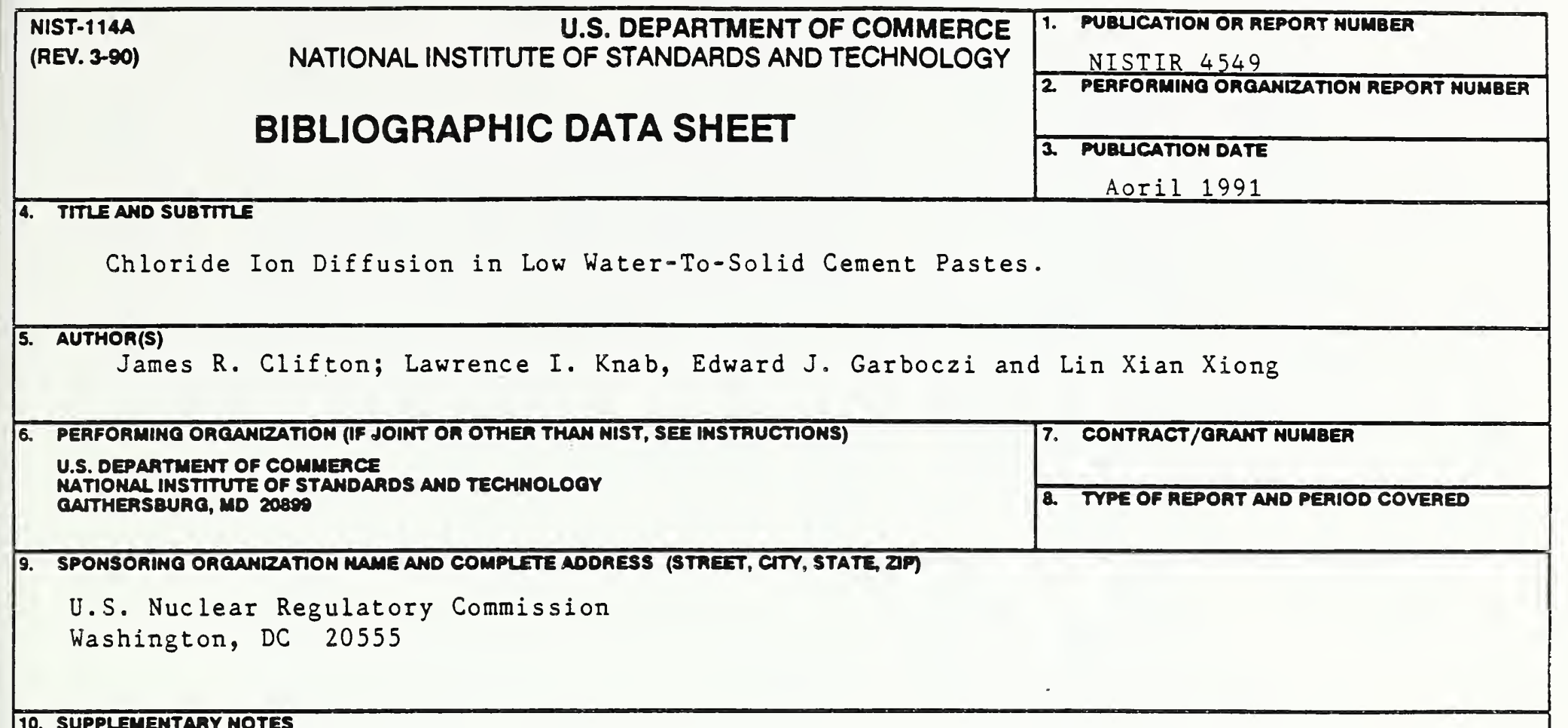

10. SUPPLEMENTARY NOTES

11. ABSTRACT (A 200-WOAD OR LESS FACTUAL SUMMARY OF MOST SIGMICANT INFORMATION. IF DOCUMENT INCUWDES A SIGNIFICANT BIBUOQRAPHY OA UTERATURE SURVEY, MENTOON IT HEAE.)

Diffusion coefficients of 0.3 water to solids rato $(w / s)$ hydrated portland cement paste specimens were measured using a conventional diffusion cell. Specimens were made from both ASTM Type I and Type II portland cements and blends containing mineral admixtures (fly ash, granulated blastfurnace slag, or silica fume). The average diffusion coefficient for the portland cement paste specimens was $14 \times 10^{-13} \mathrm{~m}^{2} / \mathrm{s}$. The diffusion coefficients for the specimens containing mineral admixtures were much more variable than those for the portland cement paste specimens. A probable cause of the variability in the test results was the presence of cracks observed in the test specimens.

The effects of the depth of concrete cover over reinforcing steel and of the chloride ion diffusion coefficient on the service life of reinforced concrete exposed to chloride ions were predicted based on a diffusion model. Based on the model, the effect of the cover was shown to be proportional to the square of the cover depth. A 10 -fold decrease in the diffusion coefficient of concrete was predicted to result in a 10 -fold increase in the predicted service life.

Based on the results of the present study, it is recommended that a new chloride diffusivity test should be developed which is applicable to concrete. A candidate test method is proposed.

12. KEY WORDS (6 TO 12 ENTRIES; ALPHAEETICAL ORDER; CAPTTALEE ONLY PROPER MAMES; AND SEPARATE KEY WOADS BY SEMICOLONS)

13.

FOR OFFICLAL DISTRIBUTION. DO NOT RELEASE TO MATIOMAL TECHNICAL INFORMATION SERVCE (NTIS).

ORDER FROM SUPERINTENDENT OF DOCUMENTS, U.S. OOVERMMENT PAINTINO OFFICE, WASHINOTON, DC 20402

ORDER FROM MATIONAL TECHMICAL INFORMATION SERVICE (MTIS), SPAIMOFIED, VA 22161.

14. NUMBER OF PAINTED PAQES

3.0

15. PRICE

$\mathrm{A} 03$ 

